Acta vet. scand. $1973,14,118-128$.

From the Department of Microbiology and Immunology and the Department of Food Hygiene, Veterinary College of Norway, Oslo.

\title{
IRRADIATION OF CHICKEN EGG WHITE
}

\section{EFFECT ON PROTEINASE INHIBITORS}

\author{
By
}

Kåre Fossum and Bjarne Underdal

FOSSUM, KÅE and BJARNE UNDERDAL: Irradiation of chicken egg white. I. Effect on proteinase inhibitors. Acta vet. scand. 1973, 14,118-128. - Commercial ovomucoid trypsin inhibitors (OMTI) and egg white were exposed to various doses of gamma irradiation, using a cobalt- 60 source. The inhibitory activity of non-irradiated and irradiated samples on bovine trypsin was tested by the Kunitz method (Kunitz 1947). The activity of the inhibitors was shown to decrease exponentially with increasing radiation dose. The $\mathrm{D}_{10}$ for OMTI was $0.6 \mathrm{Mrad}$ and for the trypsin inhibitors in the crude egg white diluted 1:5 in saline 3.0 Mrad under the conditions used. The activity of the non-irradiated and irradiated inhibitors upon various animal, microbial and plant proteinases was also determined by using the crosswise casein precipitating inhibition test (crosswise CPI-test) (Fossum 1970a). By this method, which is more sensitive than the Kunitz method, trypsin inhibitory activity in egg white could be detected after exposure to an irradiation dose of 9 Mrad. No inhibitory activity could be found against any enzyme after an irradiation dose of 15 Mrad.

Irradiation as a preservation method for egg and egg products is discussed.

irradiation; preservation; enzymes; trypsin;

inhibitors; resistance.

In addition to being perishable foods, chicken egg and egg products are often transmitters of pathogenic organisms, such as salmonella. As international trade with egg products increases, the transmission of diseases by such commodities tends to become an ever-increasing problem. The conventional heat pasteurization and sterilization have unfavourable effects on some of the properties of these products, for instance, consistency. The need for new and suitable preservation methods for extending the shelf life and, even more important, making the product bacteriologically safe, is therefore evident. During recent years much effort has been concentrated on the application of ionizing 
radiation to the preservation of food (IAEA 1963). The effects of irradiation on different salmonella bacteria in eggs, and some other products, are relatively well known (Thornley 1963, Under$d a l \&$ Rosseb $\phi$ 1972). On the other hand, insufficient knowledge is, at present, available concerning the effects on bioactive substances, as well as other chemical, biochemical and physicochemical changes caused by the irradiation of food products.

The aim of the present work was to study the influence of irradiation on the naturally occurring proteinase inhibitors in egg white. Like enzymes, these inhibitors are biologically active proteins, or proteinous compounds, the activity of which can be affected by chemical and physical influences (reviewed by Vogel et al. 1968). The influence of ionizing irradiation on such inhibitors has not previously been reported. Although inhibitors are not known to have biocatalytic activity, some of them are highly specific in inhibiting only one, or a few, enzymes. Knowledge of the fate of biologically active principles in food caused by the different preservation methods is considered to be of general importance as these components may have an influence on the shelf life of the products as well as on the digestive process in man and animals. Furthermore, such components may be used as indicators when testing the influence of physical and chemical treatments on food and feedstuffs.

\section{MATERIALS AND METHODS}

\section{Inhibitors}

Chicken egg white was aseptically collected from fresh eggs. The egg white was diluted 1:5 with saline before being transferred, in aliquots of $1 \mathrm{ml}$, to thin-walled 1-ml glass ampoules.

Trypsin inhibitor from ovomucoid (OMTI) (chicken egg white, type II-0, lot 27B-8500) was obtained from Sigma*. A solution of 2 $\mathrm{mg} / \mathrm{ml}$ in saline was placed in glass ampoules for exposure to irradiation.

The sealed ampoules were stored in an ice bath before, during and after the irradiation.

\section{Enzymes}

The following enzymes were obtained from Sigma: Trypsin from bovine pancreas (Type III, $2 \times$ crystallized, lot 97B-8000), $\alpha$-chymotrypsin from bovine pancreas (Type II, $3 \times$ crystallized, lot $86 \mathrm{~B}-$ 0470), protease from Bacillus subtilis (Type VIII, crystallized, lot 17B-

* Sigma Chemical Company, St. Louis, Mo., USA. 
2770), protease from Aspergillus oryzae (Type II, crude, lot 1320), ficin from fig tree latex $(2 \times$ crystallized, lot 119B-4750). Trypsin from hog pancreas (crystallized, batch No. 36467) was obtained from KochLight Laboratories*. Proteinases from Bacillus cereus and Corynebacterium pyogenes were prepared as described by Sandvik (1962).

\section{Irradiation}

The irradiations were carried out at the Institute of Atomic Energy, Kjeller, Norway, using a cobalt-60 source. The activity was $32,000 \mathrm{Ci}$ giving a maximum dose rate of $750 \mathrm{krad}$ per $\mathrm{hr}$. The absorbed dose was determined by placing perspex, Red-400 dosimeters together with each sample (Thomassen 1970). The dose range was from 0.5 Mrad to 15 Mrad.

\section{Assay of inhibitory activity}

A slight modification of the casein digestion method of Kunitz (1947), as previously described by Fossum (1970a), was used to determine the activity of the inhibitors against bovine trypsin. Tris-HCl buffer, $0.5 \mathrm{M}, \mathrm{pH} 7.0,0.3 \mathrm{ml}$, and distilled water, were added to the tubes to give a final volume of $1 \mathrm{ml}$, after addition of the enzyme in the absence, or presence, of inhibitor-containing materials. The enzyme-containing solution, without inhibitors, with non-irradiated inhibitors, or with inhibitors exposed to various doses of irradiation, was routinely incubated in a water bath for $2 \mathrm{~min}$. at $37^{\circ} \mathrm{C}$, after which substrate $(1 \mathrm{ml}$ of a $2 \%$ solution of casein of Hammarsten quality in $0.1 \mathrm{M}$ phosphate buffer, $\mathrm{pH}$ 7.6) was added to start the reaction. After 20 min., the reaction was stopped by adding $3 \mathrm{ml}$ of a $5 \%$ solution of trichloroacetic acid (TCA). The activity of the enzyme was determined by reading the absorbance of the supernatant at $280 \mathrm{~nm}$ using a Beckman DU spectrophotometer. The inhibition percentage caused by various amounts of the inhibitor-containing materials was calculated for each series of non-irradiated and irradiated material, and the results plotted as shown in Figs. 1 and 2.

An amount of trypsin resulting in a final optical density of $0.500-$ $0.600 \mathrm{~nm}$ in the abscence of inhibitor under the conditions described, was used $(0.025 \mathrm{ml}$ of a $0.1 \%$ solution in distilled water $)$.

The inhibitory activity was also tested by the agar casein precipitating method (CP-method) of Sandvik adapted for the determination of proteinase inhibitors, as in the crosswise casein precipitating inhibition test (Crosswise-CPI test) (Fossum 1970a). Filter paper strips (Schleicher \& Schüll No. $2043 \mathrm{bmgl}$ ) moistened with the inhibitor-containing material were placed on an agar layer $(2 \mathrm{~mm}$ deep) containing $1 \%$ sodium caseinate ( $\mathrm{pH} 6.5)$ in $1.4 \%$ agar (Bacto-

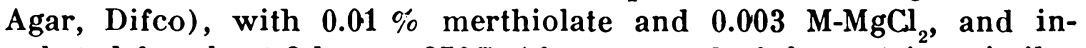
cubated for about $3 \mathrm{hrs}$. at $37^{\circ} \mathrm{C}$. After removal of these strips, similar strips moistened with solution of the proteolytic enzymes to be used were applied to the surface of the agar at right angles to the direction of

* Koch-Light Laboratories Ltd., Colnbrook, Bucks., England. 
application of the inhibitors. In the case of ficin, sulfhydryl activators were incorporated in the enzyme solution. The tightly covered plates were incubated at $37^{\circ} \mathrm{C}$ for $6-18 \mathrm{hrs}$. Proteolytic activity is indicated by white zones in the clear agar, while inhibition is indicated by interruption of the white precipitation zones, or by a certain degree of narrowing of the white zones, depending on the inhibitory activity, in the region where application of inhibitor and enzyme overlap (Figs. 4, 5). Enzyme concentrations corresponding to 10-100 CP-units per $0.025 \mathrm{ml}$ were usually used (Sandvik).

The inhibitory activity was tested $24-48 \mathrm{hrs}$. after the irradiation.

\section{RESULTS}

Preliminary irradiation experiments, using undiluted egg white, showed that coagulation occurred at doses lower than those necessary to inactivate the inhibitors. The influence of different irradiation doses on the activity of the trypsin inhibitors in egg white and OMTI is shown in Figs. 1 and 2. The inhibition was linear with respect to the amount of inhibitory material in the area investigated up to $70 \%$ inhibition. The amounts of inhibitors in the non-irradiated egg white and in OMTI equivalent to the amount of enzyme used were found by extrapolating the lines to $100 \%$ inhibition (Fossum 1970b). The percentage of inhibitory activity of the irradiated material caused by this amount was read from Figs. 1 and 2, and the logarithm

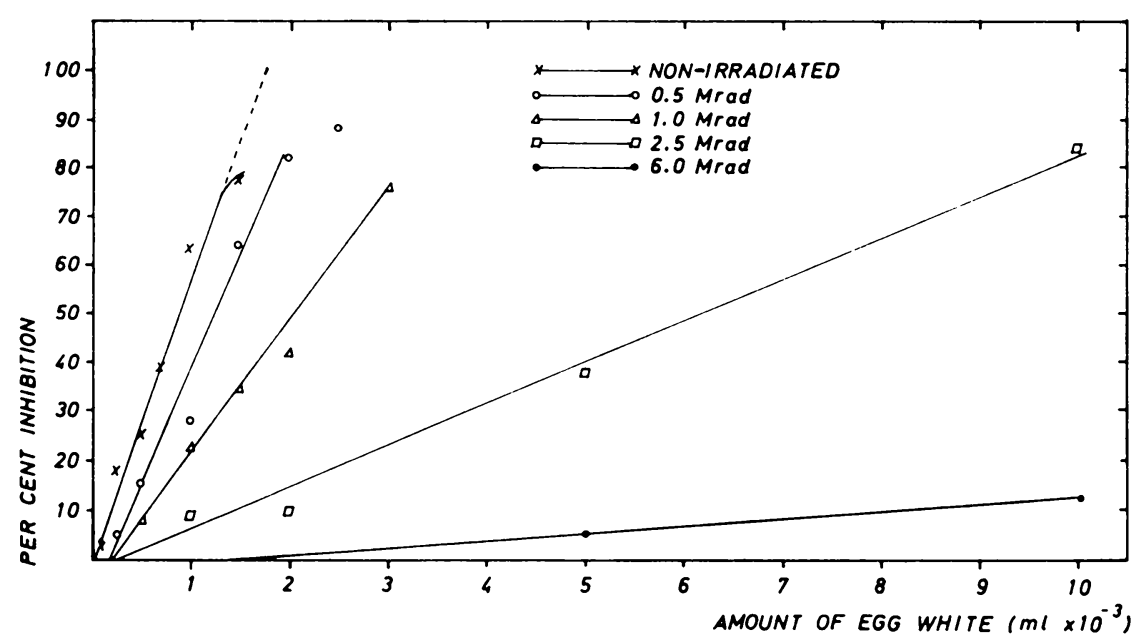

Figure 1. Percentage of inhibition of bovine trypsin $(0.025 \mathrm{mg})$ by non-irradiated and irradiated egg white as determined by the Kunitz method. 


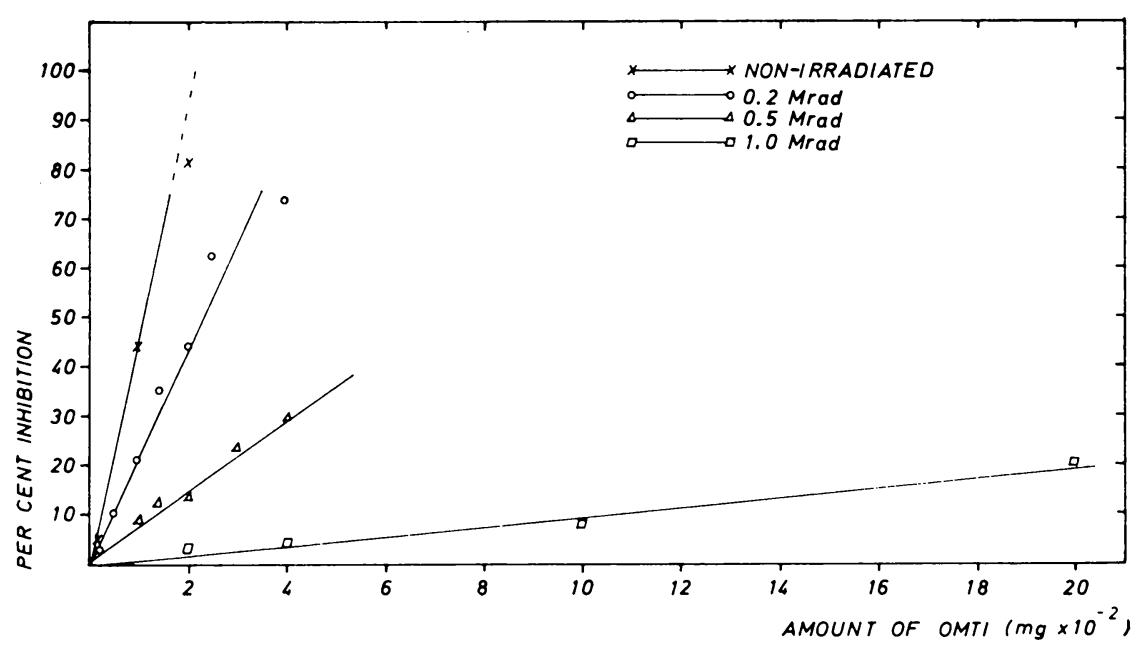

F igure 2. Percentage of inhibition of bovine trypsin $(0.025 \mathrm{mg})$ by non-irradiated and irradiated OMTI as determined by the Kunitz method.

of this activity was plotted against the irradiation dose as shown in Fig. 3. The inhibitory activity was shown to decrease exponentially with increasing radiation doses. The $\mathrm{D}_{10}$ for the trypsin inhibitory activity in egg white was $3 \mathrm{Mrad}$, and for OMTI 0.6 Mrad.

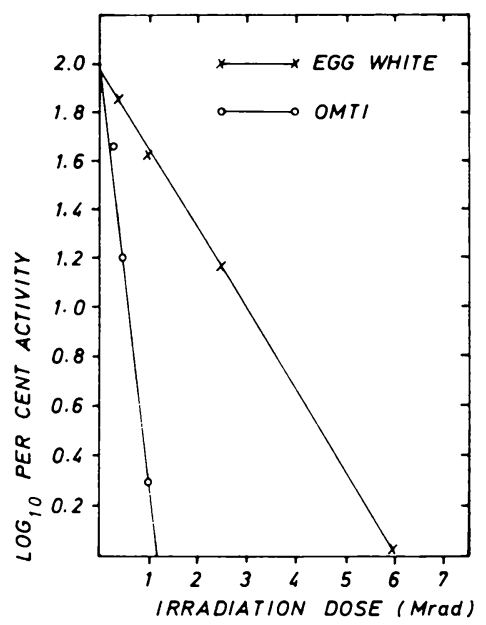

Figure 3. The logarithm of the inhibitory activity percentage of non-irradiated and irradiated egg white and OMTI read from Figs. 1 and 2, plotted against the irradiation dose. (Activity of non-irradiated material equals $100 \%$ ). 


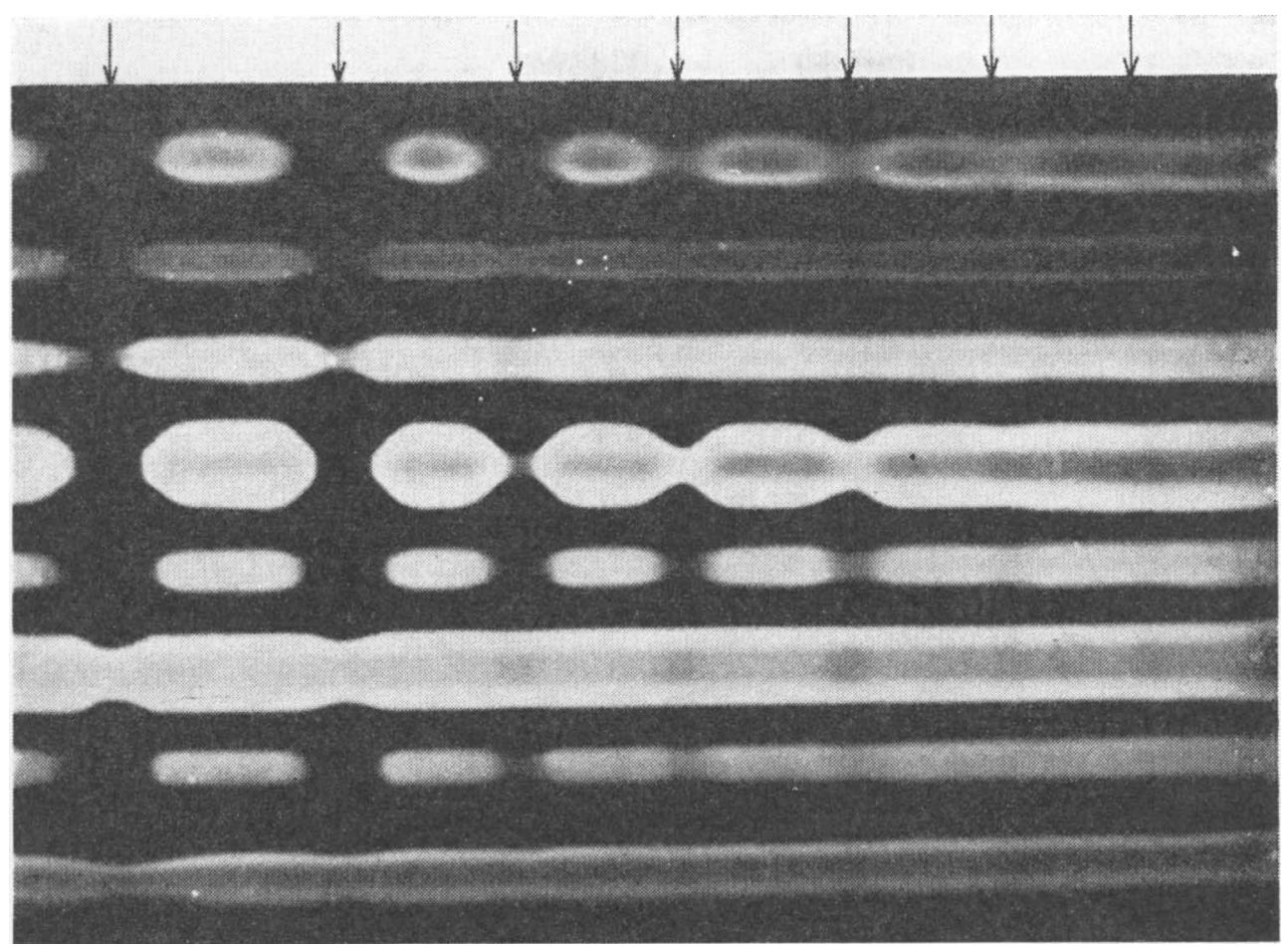

Figure 4. Crosswise CPI-test with different dilutions of nonirradiated chicken egg white. The dilutions are (from left to right as marked by arrows): 1:5, 1:10, 1:50, 1:100, 1:200, 1:500, 1:1000. Enzymes are (downwards): Swine trypsin (0.005 $\mathrm{mg}$ per $\mathrm{ml}), \alpha$-chymotrypsin $(0.005 \mathrm{mg}$ per $\mathrm{ml})$, proteinases from: Bacillus cereus, Bacillus subtilis ( $0.001 \mathrm{mg}$ per $\mathrm{ml})$, Aspergillus oryzae $(0.03 \mathrm{mg}$ per $\mathrm{ml})$, Corynebacterium pyogenes, Pseudomonas aeruginosa, and ficin $\mathbf{0 . 0 5}$ mg protein per $\mathrm{ml}$ ).

Figs. 4 and 5 illustrate the inhibitory activity of non-irradiated egg white, and egg white exposed to 4 Mrad, respectively, upon various proteolytic enzymes as investigated by the crosswise CPI-test. Non-irradiated egg white gave a zone of inhibition for some enzymes at dilutions up to 1:500, while in egg white exposed to an irradiation dose of $4 \mathrm{Mrad}$, inhibition could be registrated up to a maximum dilution 1:100. The highest dilutions of egg white, non-irradiated and irradiated, resulting in zones of inhibition, are shown in Table 1 . It can be seen that inhibitors against trypsin can be demonstrated after exposure to irradiation doses up to $9 \mathrm{Mrad}$, and inhibitors against $\mathrm{B}$. subtilis proteinase even after 12 Mrad. 


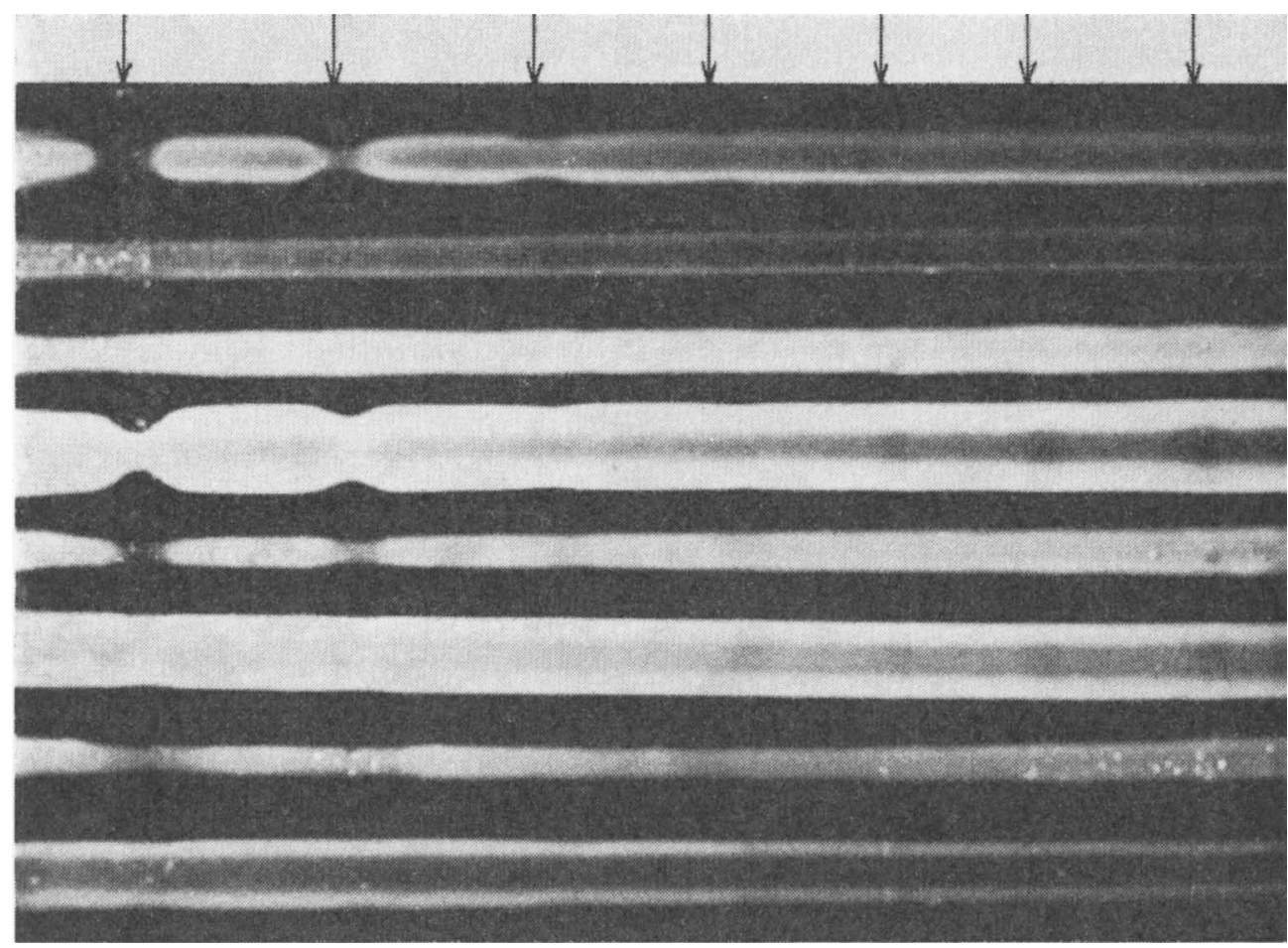

F i g u re 5. Crosswise CPI-test with different dilutions of chicken egg white exposed to an irradiation of $4.0 \mathrm{Mrad}$. The dilutions and enzymes used are the same as in Fig. 4.

T a b l e 1. The reciprocal of the highest dilution of egg white, exposed to various doses of irradiation, resulting in zones of inhibition of different proteolytic enzymes, using the crosswise CPI-test.

\begin{tabular}{lrrrrrrrrr}
\hline & \multicolumn{8}{c}{ Doses of irradiation (Mrad) } \\
\cline { 2 - 10 } Enzymes (Origin) & $\mathbf{0 . 0}$ & $\mathbf{0 . 5}$ & $\mathbf{1 . 0}$ & $\mathbf{2 . 5}$ & $\mathbf{4 . 0}$ & $\mathbf{6 . 0}$ & $\mathbf{9 . 0}$ & $\mathbf{1 2 . 0}$ & $\mathbf{1 5 . 0}$ \\
\hline Trypsin (Swine) & $500^{*}$ & 200 & 200 & 200 & 100 & 10 & 10 & $0^{* *}$ & 0 \\
-Chymotrypsin & 200 & 50 & 50 & 10 & 0 & 0 & 0 & 0 & 0 \\
Bacillus cereus & 50 & 10 & 5 & 0 & 0 & 0 & 0 & 0 & 0 \\
Bacillus subtilis & 500 & 200 & 200 & 200 & 100 & 10 & 10 & 5 & 0 \\
Aspergillus oryzae & 500 & 200 & 200 & 100 & 50 & 10 & 5 & 0 & 0 \\
Corynebacterium pyogenes & 50 & 5 & 5 & 5 & 5 & 5 & 0 & 0 & 0 \\
Pseudomonas aeruginosa & 200 & 10 & 10 & 5 & 5 & 0 & 0 & 0 & 0 \\
Ficin & 50 & 50 & 10 & 0 & 0 & 0 & 0 & 0 & 0 \\
\hline
\end{tabular}

* The egg white was diluted $1: 5,1: 10,1: 50,1: 100,1: 200,1: 500$, and $1: 1000$ in saline.

* 0 : No inhibition observed in egg white diluted 1:5. 


\section{DISCUSSION}

Many of the naturally occurring proteinase inhibitors are remarkabiy resistant to heat (Lineweaver \& Murray 1947, Laskovski \& Wu 1953, Green 1957, Kiermeier \& Semper 1959/60, Astrup \& Nissen 1964, Ryan 1966, Fossum \& Whitaker 1968). OMTI is thus reported to have about $50 \%$ of its trypsin-inhibitory activity left after heating at $100^{\circ} \mathrm{C}$ for $30 \mathrm{~min}$. at $\mathrm{pH}$ between 3 and 7 (Lineweaver \& Murray). Some enzymes, such as trypsin, are also rather heat stable. The inhibitors, like most enzymes, should also be expected to be more resistant to irradiation than microorganisms. The present work shows that the inhibitors in egg white are not completely inactivated even by doses normally used for sterilization. As can be seen from Fig. 3 the $D_{10}$ for the trypsin inhibitors in egg white is much higher than for the purified OMTI. Using the Kunitz method, inhibitory activity could not be demonstrated in egg white or in the OMTI solution after an exposure exceeding 6 and $1 \mathrm{Mrad}$, respectively. The marked difference between the influence of irradiation on purified inhibitors, and inhibitors in the crude material, is in agreement with similar experiments made with enzymes. Dahle $\&$ Underdal (1972) found a protective effect of protein in irradiation experiments with proteolytic enzymes from Aeromonas liquefaciens. In the present study the protein content in the irradiated OMTI solutions was $0.2 \%$. In the diluted egg white solutions the total protein content was approx. $2 \%$ of which OMTI constitutes about $11 \%$, or a little more than $0.2 \%$ of the total protein (Board 1969). Thus the amount of OMTI should be approximately the same in the purified OMTI solutions and in the solutions of egg white exposed to irradiation. It must be emphasized, however, that the crude egg white also contains other trypsin inhibitors, such as the ovoinhibitor (Matsushima 1958). The trypsin inhibitory activity in egg white was thus not caused by OMTI alone, and a direct comparison between the influence of irradiation on the inhibitory activity in the two systems could, therefore, give deceptive results.

From Figs. 4 and 5 and Table 1 it can be seen that trypsin inhibitory activity in chicken egg white could be detected after exposure to 9 Mrad by the crosswise CPI-test. This is in agreement with the greater sensitivity of the latter method in comparison to the Kunitz method (Fossum 1970a). 
Five electrophoretic distinguishable inhibitors have been reponted in chicken egg white, each with a special inhibitory spectrum (Fossum 1970c). It can be seen that inhibitors affecting enzymes other than trypsin are also inactivated by irradiation in the same way as the trypsin inhibitors. Inhibitory activity in 1:5 dilutions of the material tested could not be demonstrated against any enzyme after an irradiation dose of 15 Mrad. However, irradiation of whole egg white, or egg powder, would probably reveal that the inhibitors under these conditions are even more stable towards irradiation than reported here. The high resistance of these inhibitors to irradiation may be considered as beneficial when taking into account their eventual antimicrobial activity (Board) and their protection against decomposing proteolytic enzymes. Unlike the soy bean trypsin inhibitors, the inhibitors in egg white do not seem to be related to undesirable phenomena in food such as insufficient digestibility and utilization of the protein, pancreas hypertrophy, increased enzymatic activity in the intestinal content etc.

The fact that irradiation of undiluted egg white above $3-4$ Mrad caused visually observable physical changes of the product, such as increased viscosity, could be the limiting factor for complete radiation sterilization of liquid whole egg and egg products.

\section{REFERENCES}

Astrup, T. \& U. Nissen: Urinary trypsin inhibitor (mingin): Transformation into a new trypsin inhibitor by acid hydrolysis or by sialidase. Nature (London) 1964, 203, 255-257.

Board, R. G.: The microbiology of the hen's egg. Advanc. appl. Microbiol. 1969, 11, 245-281.

Dahle, $H . K . \& B$. Underdal: The effects of gamma irradiation on some properties of two Aeromonas proteinases. Acta vet. scand. 1972, 13, 492-504.

Fossum, K.: Proteolytic enzymes and biological inhibitors. I. Comparison between the Kunitz method and the agar gel casein precipitating reaction for determination of the activity of some commercial proteolytic enzymes and inhibitors. Acta path. microbiol. scand. 1970a, Section B, 78, 350-362.

Fossum, K.: Proteolytic enzymes and biological inhibitors. II. Naturally occurring inhibitors in sera from different species and their effect upon proteolytic enzymes of various origin. Acta path. microbiol. scand. $1970 \mathrm{~b}, 78,605-618$.

Fossum, K.: Proteolytic enzymes and biological inhibitors. III. Naturally occurring inhibitors in some animal and plant materials 
and their effect upon proteolytic enzymes of various origin. Acta path. microbiol. scand. 1970c, 78, 741-754.

Fossum, K. \& J. R. Whitaker: Ficin and papain inhibitor from chicken egg white. Arch. Biochem. 1968, 125, 367-375.

Green, N. M.: Protease inhibitors from Ascaris lumbricoides. Biochem. J. 1957, 66, 416-419.

IAEA: Radiation control of Salmonella in food and feed products. Techn. Rep. No. 22, 1963.

Kiermeier, F. \& G. Semper: Uber das Vorkommen eines proteolytischen Enzyms und eines Trypsin-Inhibitors in Kuhmilch. II. Mitteilung zur inhibitorischen Wirkung. (The presence of a proteolytic enzyme and a trypsin inhibitor in cow milk. II. Report on the inhibitory activity). Z. Lebensmitt.-Untersuch. $1959 / 60,111,373-380$.

Kunitz, M.: Crystalline soybean trypsin inhibitor. II. General properties. J. gen. Physiol. 1947, 30, 291-310.

Laskowski, M. \& F. C. Wu: Temporary inhibition of trypsin. J. biol. Chem. 1953, 204, 797-805.

Lineweaver, H. \& C. W. Murray: Identification of the trypsin inhibitor of egg white with ovomucoid. J. biol. Chem. 1947, 171, $565-581$.

Matsushima, K.: An undescribed trypsin inhibitor in egg white. Science 1958, 127, 1178-1179.

Ryan, C. A.: Chymotrypsin inhibitor I from potatoes: Reactivity with mammalian, plant, bacterial, and fungal proteinases. Biochemistry (Wash.) 1966, 5, 1592-1596.

Sandvik, O.: Studies on casein precipitating enzymes of aerobic and facultatively anaerobic bacteria. Thesis, Veterinary College of Norway, Oslo 1962.

Thomassen, J.: Opplegg av dosimetersystemer for gammabestrålingsanlegget på Kjeller. (Dosimeter systems for the gamma irradiation equipment at Kjeller). IAE Report IS-59, 1970.

Thornley, M. J.: Microbiological aspects of the use of radiation for the elimination of Salmonellae from foods and feeding stuffs. Radiation control of salmonellae in food and feed products. IAEA Techn. Rep. no. 22, 1963.

Underdal, B. \& L. Rosseb $\emptyset$ : Inactivation of strains of Salmonella senftenberg by gamma irradiation. J. appl. Bact. 1972, 35, 371--377.

Vogel, R., I. Trautschold \& E. Werle: Natural proteinase inhibitors. Acad. Press, New York and London 1968, 159 pp.

\section{SAMMENDRAG}

Bestråling av hønseeggehvite I. Virkningen på proteinaseinhibitorer.

Kommersiell ovomukoid trypsin inhibitor (OMTI) og eggehvite fra hønseegg ble utsatt for forskjellige doser av gammastråler fra en kobolt-60 kilde. Aktiviteten av inhibitorene i ubestrålt og bestrålt materiale ble unders $\varnothing$ kt overfor bovint trypsin etter Kunitz metode (Kunitz 1947). Den inhibitoriske aktivitet avtok eksponensielt med 
$\emptyset$ kende stråledose. Under de gjeldende fors $\varnothing$ ksbetingelser var $D_{10}$ for OMTI 0,6 Mrad og for trypsininhibitorene i rå eggehvite fortynnet 1:5 i fysiologisk saltvann var $D_{10} 3,0$ Mrad. Aktiviteten av ubestrålte og bestrålte inhibitorer overfor forskjellige animalske og mikrobielle proteinaser samt overfor ficin, ble også unders $\varnothing$ kt ved å benytte den kryssvise presipitasjonsinhibisjonstest (kryssvis CPI-test) (Fossum 1970a). Ved denne metode, som er mer sensitiv enn Kunitz metode, kunne inhibitorisk virkning overfor trypsin påvises $\mathrm{i}$ eggehvite etter en stråledose på 9 Mrad. Etter en bestråling på 15 Mrad kunne en ikke påvise noen hemmende virkning overfor noen av de unders $\varnothing$ kte enzymer.

Bestråling som konserveringsmetode for egg og eggprodukter er diskutert.

(Received April 13, 1972).

Reprints may be requested from: Kåre Fossum, The Department of Microbiology and Immunology, Veterinary College of Norway, Postbox 8146, Oslo Dep., Oslo 1, Norway. 